Univerzitet u Beogradu
Poljoprivredni fakultet
Institut za poljoprivrednu tehniku
Naučni časopis
POLJOPRIVREDNA TEHNIKA
Godina XLVI
Broj 2, 2021.
Strane: $56-66$

\title{
OPTIMIZATION OF BIO-LUBE PRODUCTION USING THE AUTOMATED FUZZY LOGIC CONTROLLED TEMPERATURE BIOREACTOR AND D-OPTIMAL DESIGN
}

\author{
Peter Obasa $^{*}{ }^{1}$, Bolanle Adejumo ${ }^{1}$ \\ ${ }^{I}$ Department of Agricultural and Bioresources Engineering, \\ Federal University of Technology, Minna, Nigeria
}

\begin{abstract}
Optimization of process parameters of many existing biolubricant were carried out based on the factor interactions and yield without putting the physicochemical properties into consideration. The aim of the work is to optimize the reaction temperature and time for the production of high-quality biolubricant using set objectives in relation to the physicochemical properties of the bio-lube produced. The reactor used consists of a reactor tank $\left(2500 \mathrm{~cm}^{3}\right)$, temperature, time, stirrer (agitation), speed ranged between $0-300{ }^{\circ} \mathrm{C}, 0-120$ minutes and $80-500 \mathrm{rpm}$ respectively. The optimum temperature and time design matrix using Response Surface Methodology (Doptimal design) in Design Expert 11.0 software package. The results of the optimized yield of the castor seed oil biolubricant produced were compared with international standards for lubricant. The result shows better yield in the operational process of the fuzzy logic-controlled reactor. The yield of biolubricant for the experimental design matrix produced using the fuzzy logic reactor ranged between $79-96 \%$. Higher values were obtained from the study, except for the pour point values that were lower. The higher yield and the physical and thermal properties in castor oil biolubricant from the fuzzy logic temperature-controlled reactor could be as result of the uniform temperature and reaction time during the production process. The optimum condition for the bio-lube produced considering the optimum set goals for best quality biolubricant produced considering the set goal objective to comprise all the physico-thermal properties obtained in the study.
\end{abstract}

\footnotetext{
* Corresponding Author. E-mail: peter.obasa@futminna.edu.ng
} 
The optimum condition was obtained at ninety-nine (99.5) minutes reaction time and $250{ }^{\circ} \mathrm{C}$ reaction temperature with desirability value of 0.76 . with the physico-thermal properties of $96.48 \%, 33.7 \mathrm{mPa} . \mathrm{s}(33.7 \mathrm{cP}), 15.5 \mathrm{mPa} . \mathrm{s}(15.5 \mathrm{cP}), 179.9{ }^{\circ} \mathrm{C}, 291{ }^{0} \mathrm{C}$, $15.9{ }^{\circ} \mathrm{C}$, for viscosity at $40{ }^{\circ} \mathrm{C}$, viscosity at $100{ }^{\circ} \mathrm{C}$, viscosity Index, Flash point, pour point. The physicochemical properties of biolubricant produced at optimum condition are within the recommended international standard. It can be concluded that the fuzzy logic-controlled reactor product is better biolubricant considering the number of parameters set goal to determine the optimum condition for production.

Key words: Bio-lube, D-optimal, Numerical, Physico-thermal, Point-prediction

\section{INTRODUCTION}

Engine oil is prominent amongst the most widely recognized lubricants and well utilized in engineering concepts. Conventional lubricants produce a non-clean, highly toxic working environment due to the burning of lubricant as fuel to generate power. Basic disposal strategies which incorporate recycling, copying, landfill and release into water, is one of the major constraints in developing countries [1], [2].

Research has been conducted to have environmentally friendly lubricants that can be used in place of the conventional lubricants which are called biolubricant [3]. The best application for biolubricant is in machinery that loses oil directly into the environment during use, Total Loss Lubricants (TLLs), and in machinery used in any sensitive areas, such as in or near water. Applications for TLLs include two-stroke engines, chain saw bars and chains, railroad flanges, cables, dust suppressants, and marine lubricants [4], $[5]$.

\section{MATERIAL AND METHODS}

The experimental design used for the synthesis of castor oil bio lubricant was optimized with the aid of response surface methodology (RSM) using D-optimal design approach. This methodology is used to scrutinize the relationship between the response variable and a set of experimental factors. A polynomial equation was used to predict the response as a function of independent variables and their interactions. In this work, the number of independent variables was two and therefore the response for the quadratic, cubic polynomials become $Y=\beta 0+\Sigma \beta i x i+\Sigma \beta i i x i^{2}+\Sigma \Sigma \beta i j x i x j$ (1). Where $\beta 0 ; \beta i$; $\beta i i$ and $\beta i j$ are constant, linear, square and interaction regression coefficient terms, respectively, and $x i$ and $x j$ are independent variables Table 1 . The design expert software version 11 was used for multiple regression analysis, analysis of variance (ANOVA), optimization analysis set goals data and the response surface regression procedure. The lack of fit of the model was evaluated by the coefficient of determination $\mathrm{R}^{2}$, adjustable $\mathrm{R}^{2}$ and its statistical significance that was checked by the $\mathrm{P}$-value and $F$-test. Automated Fuzzy Logic Controlled Temperature Bioreactor was used for all the reactions [6]. 
Table 1. Independent Variables and Their Levels for Response Surface Methodology, D-Optimal Design Response Surface methodology for the Transesterification Reaction of castor oil ester

\begin{tabular}{|c|c|c|c|}
\hline Independent variables & \multicolumn{3}{|c|}{$\begin{array}{c}\text { Variable } \\
\text { Levels }\end{array}$} \\
\hline & & -1 & +1 \\
\hline Time & $\mathrm{X}_{1}$ & 30 & 120 \\
\hline Temperature & $\mathrm{X}_{2}$ & 100 & 250 \\
\hline
\end{tabular}

The experimental factors for this experiment are temperature and time. The two (2) experimental factors were used to establish the number of experimental runs which was given as 13 runs. The details of the factor - levels and values obtain using RSM are as presented in the design matrix Table 2.

Table 2. Experimental matrix design for the optimization of the Transesterification reaction process for biolubricant production

\begin{tabular}{|c|c|c|c|c|}
\hline \multicolumn{3}{|c|}{ Coded factor } & \multicolumn{2}{c|}{ Actual factor } \\
\hline Run & $\mathrm{X}_{1}$ : Time & $\mathrm{X}_{2}:$ Temperature & $\mathrm{X}_{1}:$ Time & $\mathrm{X}_{2}$ : Temperature \\
\hline 1 & -1.00 & -1.00 & 30 & 100 \\
\hline 2 & -0.11 & -0.15 & 70 & 164 \\
\hline 3 & 1.00 & 0.33 & 120 & 200 \\
\hline 4 & 0.00 & -1.00 & 75 & 100 \\
\hline 5 & 0.47 & 1.00 & 96 & 250 \\
\hline 6 & 0.62 & -0.25 & 103 & 156 \\
\hline 7 & -0.25 & 0.57 & 64 & 218 \\
\hline 8 & -1.00 & 0.00 & 30 & 175 \\
\hline 9 & -0.61 & -0.50 & 48 & 100 \\
\hline 10 & -1.00 & -1.00 & 30 & 250 \\
\hline 11 & -1.00 & 1.00 & 30 & 100 \\
\hline 12 & 1.00 & -1.00 & 120 & 250 \\
\hline 13 & -1.00 & 1.00 & 30 & \\
\hline
\end{tabular}

\section{Characterization of castor oil biolubricant}

Physicochemical properties of castor oil biolubricant were carried out using the American Standard Testing Methods [8]. The main properties of lubricant oil required for good performance were carried out.

These properties are:

\section{Determination of Acid Value and Free Fatty Acid}

One gram $(1 \mathrm{~g})$ of oil was placed inside $100 \mathrm{ml}$ beaker, $25 \mathrm{ml}$ of petroleum ether with $25 \mathrm{ml}$ of alcohol (methanol) was added, 4 drops of phenolphthalein was added as an 
indicator and mixed thoroughly, after that, the solution was titrated against $0.1 \mathrm{M} \mathrm{KOH}$ until the end point was reached that is there was colour change which turn to pink. [6].

The Acid Value and Free Fatty Acid (mgKOH/g) was calculated as:

$$
\begin{gathered}
\text { Acid Value }=\frac{\text { Titre }(\mathrm{ml}) \times 0.1 \times 56.10}{\text { Weight of Sample }(1 \mathrm{~g})} \\
\text { Free Fatty Acid }=\frac{\text { Acid Value }}{2}
\end{gathered}
$$

\section{Determination of viscosity and Viscosity Index (VI)}

Viscosity of the oleo-chemicals was determined using a viscometer. Two hundred millilitres $(200 \mathrm{ml})$ of the sample was poured into a beaker and heated to $40{ }^{\circ} \mathrm{C}$ and 100 ${ }^{0} \mathrm{C}$ respectively. A desired rotor number of the viscometer was attached to the upper coupling between the thumb and forefinger while cautiously rotating the rotor in anticlockwise direction. The rotor was immersed in the middle of the sample up to the indentation level on the shaft.

The viscometer was then switched and let to run at $60 \mathrm{rpm}$. The result was obtained and recorded as the viscosity of the sample in $\mathrm{mPa} s(\mathrm{cP})$ [9].

The result at $40{ }^{\circ} \mathrm{C}$ and $100{ }^{\circ} \mathrm{C}$ was used to calculate the Viscosity Index

$$
\text { Viscosity Index }(V I)=\frac{L-U}{L-H} \times 100
$$

\section{Determination of Pour Point}

This was measured according to ASTM D97. A medium sized test tube was filled with the oil sample and (the test tube with its content) then be placed in a test tube holder. The set up was then placed in a refrigerator and allowed to solidify. After it solidified, the test tube was removed and a thermometer was used to read the temperature of the solidified sample.

\section{Flash Point Determination}

heat was supplied to a $10 \mathrm{ml}$ of the sample in crucible to raise the temperature of the sample. A thermometer probe was suspended in the sample with a retort stand. The flash point obtained was the minimum temperature at which the vapour of the sample ignited when a flame was brought near [10].

\section{RESULTS AND DISCUSSION}

Castor oil methyl ester (biodiesel) feed stock was used in production biolubricant using response surface methodology, D-optimal experimental design. 
The response of the experiment as presented in Table 3 shows the different actual factorlevels and their corresponding actual yield in percentage and the physico-thermal properties. [8].

Table 3. Response analysis of biolubricant Yield and physicothermal properties

\begin{tabular}{|c|c|c|c|c|c|c|c|c|}
\hline & Factor 1 & Factor 2 & Response 1 & $\begin{array}{c}\text { Response } \\
2\end{array}$ & $\begin{array}{c}\text { Response } \\
3\end{array}$ & $\begin{array}{c}\text { Response } \\
4\end{array}$ & $\begin{array}{c}\text { Response } \\
5\end{array}$ & $\begin{array}{c}\text { Response } \\
6\end{array}$ \\
\hline Run & $\begin{array}{l}\text { A: } \\
\text { Time }\end{array}$ & $\begin{array}{c}\text { B: } \\
\text { Temperature }\end{array}$ & $\begin{array}{c}\text { Biolubricant } \\
\text { Yield }\end{array}$ & $\begin{array}{c}\text { Viscosity } \\
@ 40\end{array}$ & $\begin{array}{c}\text { Viscosity } \\
@ 100\end{array}$ & $\begin{array}{c}\text { Viscosity } \\
\text { index }\end{array}$ & $\begin{array}{l}\text { Flash } \\
\text { Point }\end{array}$ & $\begin{array}{l}\text { Pour } \\
\text { point }\end{array}$ \\
\hline 1 & 30 & 100 & 79 & 31 & 7.5 & 166.282 & 275 & -18 \\
\hline 2 & 70 & 164 & 84.5 & 35 & 10 & 173.839 & 269 & -15 \\
\hline 3 & 120 & 200 & 91 & 37 & 12 & 175.612 & 281 & -16 \\
\hline 4 & 75 & 100 & 84 & 32 & 9 & 174.904 & 269 & -19 \\
\hline 5 & 96 & 250 & 96 & 34 & 18 & 176.365 & 294 & -15 \\
\hline 6 & 103 & 156 & 86.5 & 30 & 11 & 182.823 & 288 & -15 \\
\hline 7 & 64 & 218 & 88 & 32.5 & 14 & 180.643 & 290 & -16 \\
\hline 8 & 30 & 175 & 83 & 35 & 10 & 173.839 & 285 & -14 \\
\hline 9 & 48 & 138 & 81 & 37 & 12 & 175.612 & 277 & -17 \\
\hline 10 & 30 & 100 & 79 & 32 & 8.5 & 172.152 & 263 & -19 \\
\hline 11 & 30 & 250 & 94 & 37.5 & 15 & 176.43 & 285 & -14 \\
\hline 12 & 120 & 100 & 83 & 34 & 9 & 171.073 & 260 & -18 \\
\hline 13 & 30 & 250 & 93 & 33 & 13 & 180.163 & 291 & -15 \\
\hline
\end{tabular}

A numerical, graphical and privative optimization method was used to analyze the data collected from two process parameters (Time and Temperature) to generate the best operational conditions that will convene all goals set (Table 4). To obtain the desirability index for biolubricant produce with relation to the investigated physicochemical properties qualities. Goals were set for each condition and properties at maximum, minimum and in-range for castor oil biolubricant produced. 
Table 4. Numerical Optimization Constraints for Biolubricant Produced

\begin{tabular}{|l|c|c|c|c|c|c|}
\hline \multicolumn{1}{|c|}{ Name } & Goal & Lower Limit & $\begin{array}{c}\text { Upper } \\
\text { Limit }\end{array}$ & $\begin{array}{c}\text { Lower } \\
\text { Weight }\end{array}$ & $\begin{array}{c}\text { Upper } \\
\text { Weight }\end{array}$ & Importance \\
\hline A:Time & is in range & 30 & 120 & 1 & 1 & 3 \\
\hline B:Temperature & is in range & 100 & 250 & 1 & 1 & 3 \\
\hline Biolubricant Yield & maximize & 79 & 96 & 1 & 1 & 3 \\
\hline Viscosity @ 40 & minimize & 30 & 37.5 & 1 & 1 & 3 \\
\hline Viscosity @ 100 & maximize & 7.5 & 18 & 1 & 1 & 3 \\
\hline Viscosity index & maximize & 166.282 & 182.823 & 1 & 1 & 3 \\
\hline Flash Point & maximize & 260 & 294 & 1 & 1 & 3 \\
\hline Pour point & minimize & -19 & -14 & 1 & 1 & 3 \\
\hline
\end{tabular}

The predicted result shows that operational condition that gave fourteen desirability solution the best confidence interval in terms of physico-thermal properties and biolubricant yield are $96.48 \%, 33.7 \mathrm{mPa} . \mathrm{s}(33.7 \mathrm{cP}), 15.5 \mathrm{mPa} . \mathrm{s}(15.5 \mathrm{cP}), 179.9{ }^{0} \mathrm{C}$, $291{ }^{0} \mathrm{C},-15.9{ }^{0} \mathrm{C}$, respectively for biolubricant yield, viscosity at $40{ }^{\circ} \mathrm{C}$, Viscosity at 100 ${ }^{0} \mathrm{C}$, viscosity index, flash point and pour point (Table 5). The desirability with functional object which vary between 0 and 1 with relation to all parameter goals set on the numerical optimization, the selected desirability condition value of the two available solution for the castor oil biolubricant yield and physicochemical properties was 0.76 was the highest desirability value with time and temperature condition of 99.5 minutes and $250{ }^{\circ} \mathrm{C}$ respectively. 
Table 5. Numerical Optimization desirability Solutions of the produced Biolubricant

\begin{tabular}{|l|l|l|l|r|r|r|r|r|l|}
\hline Num & Time & Temp. & $\begin{array}{c}\text { Biolub. } \\
\text { Yield }\end{array}$ & $\begin{array}{r}\text { Viscosity } \\
\text { @ 40 }\end{array}$ & $\begin{array}{c}\text { Viscosity } \\
\text { @ 100* }\end{array}$ & $\begin{array}{c}\text { Viscosity } \\
\text { index }\end{array}$ & $\begin{array}{c}\text { Flash } \\
\text { Point }\end{array}$ & $\begin{array}{c}\text { Pour } \\
\text { point }\end{array}$ & Desirability \\
\hline 1 & 99.54 & 250.00 & 96.48 & 33.70 & 15.50 & 179.90 & 291.00 & -15.8 & 0.76 \\
\hline 2 & 99.86 & 250.00 & 96.49 & 33.71 & 15.56 & 179.91 & 291.00 & -15.8 & 0.76 \\
\hline 3 & 99.31 & 250.00 & 96.47 & 33.70 & 15.49 & 179.89 & 291.01 & -15.8 & 0.76 \\
\hline 4 & 100.79 & 250.00 & 96.53 & 33.73 & 15.51 & 179.93 & 290.99 & -15.8 & 0.76 \\
\hline 5 & 98.32 & 250.00 & 96.43 & 33.67 & 15.48 & 179.87 & 291.02 & -15.8 & 0.76 \\
\hline 6 & 97.78 & 250.00 & 96.41 & 33.66 & 15.47 & 179.85 & 291.03 & -15.8 & 0.76 \\
\hline 7 & 102.01 & 250.00 & 96.58 & 33.76 & 15.53 & 179.97 & 290.97 & -15.8 & 0.76 \\
\hline 8 & 104.36 & 250.00 & 96.67 & 33.83 & 15.57 & 180.03 & 290.94 & -15.9 & 0.75 \\
\hline 9 & 93.12 & 250.00 & 96.22 & 33.58 & 15.41 & 179.72 & 291.08 & -15.8 & 0.75 \\
\hline 10 & 91.41 & 250.00 & 96.15 & 33.55 & 15.38 & 179.68 & 291.10 & -15.8 & 0.74 \\
\hline 11 & 108.74 & 250.00 & 96.83 & 33.98 & 15.63 & 180.15 & 290.89 & -15.9 & 0.73 \\
\hline 14 & 88.76 & 250.00 & 96.04 & 33.52 & 15.35 & 179.60 & 291.14 & -15.7 & 0.72 \\
\hline \hline
\end{tabular}

*Intervals adjusted for variation in the factors (POE).

The solutions within one and eight can be considered usable all depending on the properties rely on biolubricant grade. The responses optimisation is comparable to research work by [11], that the Jatropha bio-lubricant yield increased with increase in temperature over time variation.

Graphical optimisation Overlay plot in Figure 1 shows the coefficient magnitudes and significance for all analysed responses in the numerical optimisation solution of the experimental factors that makes it easy to see what terms are common to all the response models, displays the area of feasible response values in the factor space. 

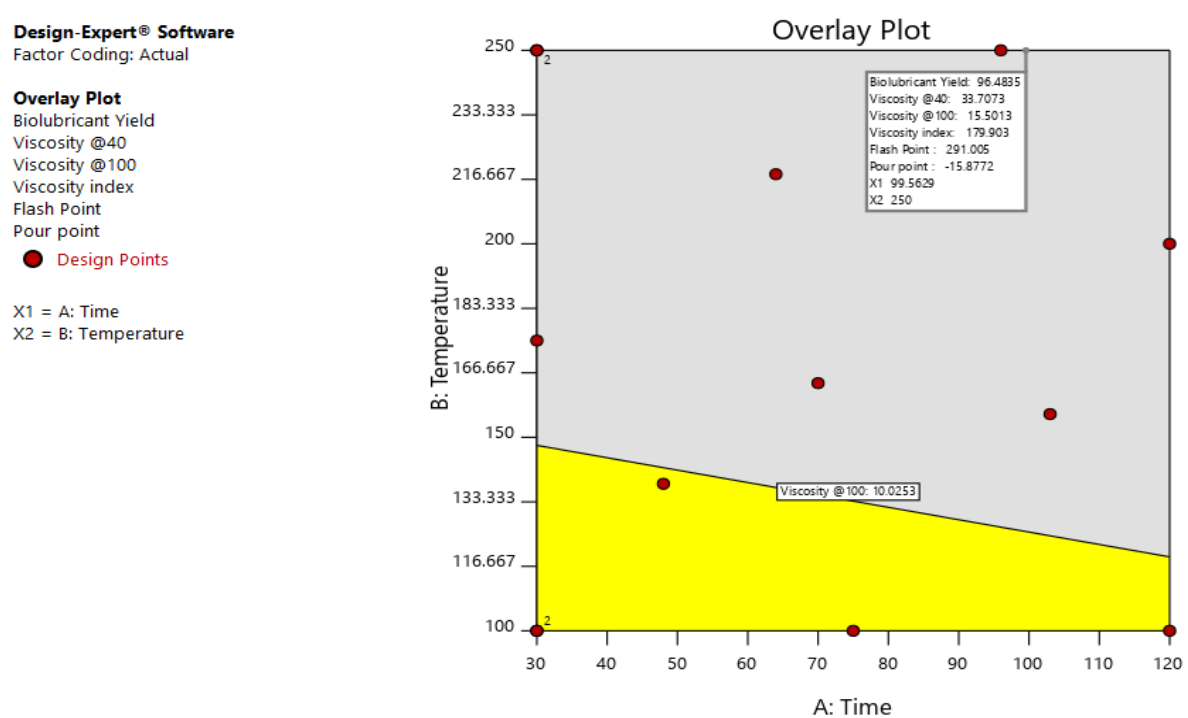

Figure 1. Optimisation Overlay plot of biolubricant in relation to Temperature and Time

On the plot, the bright yellow points range between temperature of $100-148{ }^{0} \mathrm{C}$ with time of 30 to 120 minutes shows where the entire range of all intervals of the produced biolubricant meet the specified standards that best conciliation can be picked (the sweet spot). The dray colour corresponds to where the point estimate meets the criteria requirements, but part of an interval estimate does not. The standard best conciliation shows that the reaction of the biolubricant will be best done at the sweet spot zone considering only the experimental factors, while the dray shot in consideration of all the tested parameters of the produced castor oil biolubricant. The point prediction of produced biolubricant (Table 6) shows the two-sided points (low and high) of the experimental responses to assist in the uses of prediction and interval estimates at a confidence interval of ninety five percent. The predicted mean, median, standard deviation of all the responses was within standard biolubricant. 
Table 6. Point Prediction of produced castors oil biolubricant properties

\begin{tabular}{|l|l|l|l|l|l|l|l|l|}
\hline \multicolumn{1}{|c|}{ Response } & $\begin{array}{c}\text { Predicted } \\
\text { Mean }\end{array}$ & $\begin{array}{c}\text { Predicted } \\
\text { Median }\end{array}$ & $\begin{array}{c}\text { Std. } \\
\text { Dev }\end{array}$ & $\begin{array}{c}\text { SE } \\
\text { Mean }\end{array}$ & $\begin{array}{c}95 \% \text { CI } \\
\text { low for } \\
\text { Mean }\end{array}$ & $\begin{array}{c}95 \% \text { CI } \\
\text { high for } \\
\text { Mean }\end{array}$ & $\begin{array}{c}95 \% \text { TI } \\
\text { low for } \\
99 \% \text { Pop }\end{array}$ & $\begin{array}{c}95 \% \text { TI } \\
\text { high for } \\
99 \% \text { Pop }\end{array}$ \\
\hline Biolubricant & 97.2138 & 97.2138 & 1.325 & 1.59 & 93.43 & 100.98 & 87.75 & 106.67 \\
\hline Yield & 34.4622 & 34.4622 & 2.686 & 3.23 & 26.81 & 42.11 & 15.28 & 53.64 \\
\hline Viscosity @40 & 15.7904 & 15.7904 & 1.430 & 0.95 & 13.65 & 17.92 & 8.183 & 23.39 \\
\hline Viscosity index & 180.462 & 180.462 & 3.618 & 2.42 & 175.0 & 185.86 & 161.22 & 199.70 \\
\hline Flash Point & 290.756 & 290.756 & 6.699 & 4.48 & 280.7 & 300.74 & 255.13 & 326.37 \\
\hline Pour point & -15.946 & -15.946 & 0.907 & 1.09 & -18.5 & -13.36 & -22.42 & -9.470 \\
\hline
\end{tabular}

Two-sided Confidence $=95 \%$ Population $=99 \%$

\section{CONCLUSIONS}

The research statistical data analysis clearly shows that the responses parameters as significant effect on the optimization process of castor oil biolubricant as the overlay point shows the sweet spots range of $100-148{ }^{\circ} \mathrm{C}$ temperature with time of 30 to 120 minutes with prediction mean biolubricant yield of $97.21 \%$ and the optimization process desirability function of both the factors and the responses have biolubricant yield of $96.4 \%$ at desirability of 0.76 at $250{ }^{\circ} \mathrm{C}$ temperature with time of 99.5 minutes. But the desirability optimisation gives the optimisation in terms of best quality of biolubricant.

\section{REFERENCES}

[1] Wagner, H., Luther, R., Mang, T. 2001. Lubricant base fluids based on renewable raw materials. Their catalytic manufacture and modification. Applied Catalysis. A: Gen. (2001) 221, 429-442. https://www.sciencedirect.com/science/article/abs/pii/S0926860X01008912.

[2] ATSDR (Agency for Toxic Substances \& Disease Registry 2009. Posted at: http://www.atsdr. cdc.gov/.

[3] Dormo N, Elafi-Bak K.B, Barth L. 2004. Ehrenstein U, and Gubicza L., Manufacture of an environmental-safe bio-lubricant from fuel oil by enzymatic esterification in solvent- free system, Biochemical Engineering Journal 21., pp. 229-234, https://hrcak.srce.hr/file/34893.

[4] Jaina, A. K., and Suhanea, A. 2013. Capability of Biolubricants as Alternative Lubricant in Industrial and Maintenance Applications. http://inpressco.com/wpcontent/ uploads/2013/03/ b Paper 25179-1831.pdf., pp. 23.

[5] Environmentally Preferable purchasing fact sheet biolubricants. 2011. Department of ecology Washington. www.fotress.wa.gov_biodiesel. 
[6] Obasa P.A and Adejumo B.A. 2017. Development of an Automated Fuzzy Logic Controlled Reactor for Production of Oleo-Chemical Proceedings of 18th International Conference and 38th Annual General Meeting of the Nigeria Institution of Agr. Engineers (NIAE), Umudike. pp.10-14.

https://www.researchgate.net/publication/334291277_Development_of_an_Automated_Fuzz y_Logic_Controlled_Reactor_for_Production_of_Oleo-chemicals.

[7] ASTM (The American Society for Testing and Materials).2009. Contaminants in Used oils and their Behavior. Postedat: http://www.astm.org/DIGITAL_LIBRARY/ JOURNALS/ JAI/PAGES/1274.html.

[8] Adejumo, B. A, Agboola, J. B, Orhevba, B. A, Obasa, P. A, Simeon, M. I. 2019.Optimisation of the production parameters of Delonix Regia Methyl ester using boxBehnken design. Intern. Journal of Scientific \& Technology Research. Vol. 8, Issue 09, September ISSN 2277-8616.

https://www.researchgate.net/publication/343335385_Optimisation_Of_The_Production_Par ameters_Of_Delonix_Regia_Methyl_Ester_Using_Box-Behnken_Design.

[9] Ro drogues, S., Mazzone, I.C., and Santos, F.F. P. 2009. Optimization of the production of ethyl esters by ultra-sound assisted reaction of soybean oil and ethanol, Brazilian Journal of Chemical Engineering .Vol. 26. Issue 2, pp. 361-363.

http://acascipub.com/International\%20Journal\%20of\%20Bioresource\%20Technology/IJBT Vol.\%201,\%20No.\%201,\%20February\%202013/Optimization\%20of\%20biodiesel\%20produ ction $\% 20$ from $\% 20$ nonedible $\% 20$ seeds $\% 20$ of $\% 20$ Delonix $\% 20$ regia $\% 20 \% 20$ Gul\%20Mohr.p df.

[10] Tariq, Z., Ullah, K., and Sharma, V. K. 2012. Bitter Almond oil as a non-edible feedstock for biodiesel production. Abstract of the $3^{\text {rd }}$ International workshop on renewable energy for sustainable development in Africa, Enugu, pp. 31, https://dergipark.org.tr/tr/download/article-file/867640.

[11] Bilal S, Mohammed-Dabo I., Nuhu M, Kasim, S. A, Almustapha I. H and Yamusa Y. A. 2013. Production of biolubricant from Jatropha curcas seed oil. Journal of Chemical Engineering and Materials Science. Volume. 4(6), pp. 72-79. https://academicjournals.org/ journal/JCEMS/article-abstract/30CDCB740104.

\section{OPTIMIZACIJA PROIZVODNJE BIOMAZIVA KORIŠĆENJEM AUTOMATIZOVANE FUZZY LOGIČKE KONTROLE TEMPERATURNOG BIOREAKTORA SA D-OPTIMALNIM DIZAJNOM}

\section{Peter Obasa, Bolanle Adejumo}

Department of Agricultural and Bioresources Engineering, Federal University of Technology, Minna, Nigeria

Sažetak: Optimizacija procesnih parametara mnogih postojećih biomaziva izvršena je na osnovu interakcije faktora i prinosa bez uzimanja u obzir fizičkohemijskih osobina biomaziva. Cilj rada je optimizacija temperature, reakcije i vremena za proizvodnju visokokvalitetnog biomaziva pomoću postavljenih ciljeva u odnosu na fizičkohemijske osobine proizvedenog biomaziva. 
Reaktor ima parametre: rezervoar od $2500 \mathrm{~cm}^{3}$, temperature od 0 do $300^{\circ} \mathrm{C}$, vreme reakcije od 0 do 120 minuta, i brzinu mešanja koja se kretala 80 - 500 rpm .

Matrica optimalnog dizajna temperature i vremena, kontroliše se primenom metodologije optimalne površine (D-optimalni dizajn) sa softverskim paketom Design Ekpert 11.0.

Rezultati optimizovanog prinosa proizvedenog biomaziva od ricinusovog ulja upoređivani su sa međunarodnim standardima za maziva.

Rezultat pokazuje bolji prinos u operativnom procesu logički kontrolisanog reaktora.

Prinos biomaziva dobijen sa dizajnom eksperimentalne matrice, proizvedenog pomoću fuzzy reaktora, kretao se između 79 - 96\%. Dobijene su veće vrednosti iz studije, osim vrednosti tačke prelivanja, koje su bile niže. Veći prinos, fizička i termička svojstva u biomazivu od ricinusovog ulja iz reaktora sa fuzzy (nepreciznom) kontrolom, mogu biti rezultat ujednačene temperature $\mathrm{i}$ vremena reakcije tokom proizvodnog procesa. Iz studije su dobijene veće vrednosti, osim vrednosti za tačke prelivanja koje su bile niže.

Veći prinos i fizičko- termičke osobine za biomazivo ricinusovog ulja iz reaktora sa fuzy kontrolom temperature mogu biti rezultat ujednačene temperature i vremena reakcije tokom proizvodnog procesa.

Optimalni uslov za proizvedeno biomazivo uzimajući u obzir optimalno postavljene ciljeve za najkvalitetnije proizvedeno biomazivo, uzimajući u obzir postavljeni cilj koji treba da obuhvati sve fizičko-termičke osobine koje su dobijene u studiji.

Optimalni uslovi su dobijeni u toku 99,5 minuta vremena reakcije i temperature u reaktoru od $250^{\circ} \mathrm{C}$, sa poželjnim vrednostima od 0,76 ., i fizičko-termičkim osobinama od: $96,48 \%, 33,7$ mPa.s $(33.7 \mathrm{cP}), 15,5 \mathrm{mPa} . \mathrm{s}(15.5 \mathrm{cP}), 179,9^{\circ} \mathrm{C}, 291^{\circ} \mathrm{C},-15,9^{\circ} \mathrm{C}$, za viskozitet biomaziva na $40^{\circ} \mathrm{C}$, za viskozitet na $100^{\circ} \mathrm{C}$, indeks viskoznosti, tačku paljenja, tačku tečenja biomaziva.

Fizičko-hemijske osobine biomaziva proizvedenog u optimalnim uslovima su u okviru preporučenih međunarodnih standarda.

Može se zaključiti da je produkt sa fuzzy logikom (neprecizna logika) kontrolisane proizvodnje reaktora, bolje biomazivo, obzirom na broj postavljenih kontrolisanih parametara za određivanje optimalnih uslova proizvodnje.

Ključne reči: Biomaziva, D-optimalni dizajn, Numeričko, Fizičko-termičke osobine, tačkasto predviđanje

Prijavljen:

Submitted: 07.02.2021.

Ispravljen:

Revised: 08.03.2021.

Prihvaćen:

Accepted: 10.04.2021. 